\title{
Perubahan Lahan Pertanian dan Kehutanan di Kota Langsa dalam Kurun Waktu 10 Tahun (2007 - 2016)
}

\author{
(The Changes of Agricultural and Forest Land Use in Langsa City \\ During 10 years (2007 - 2016))
}

\author{
Siti Rahmatika ${ }^{1}$, Syakur $^{1}$, Muhammad Rusdi ${ }^{*}$ \\ ${ }^{1}$ Program Studi Ilmu Tanah, Fakultas Pertanian, Universitas Syiah Kuala
}

\begin{abstract}
Abstrak. Penelitian ini bertujuan untuk melihat perubahan penggunaan lahan pertanian dan kehutanan yang terjadi di masing-masing Kecamatan yang ada di Kota Langsa dalam waktu 10 tahun, mulai dari tahun 2007 sampai 2016. Teknik yang digunakan yaitu digitasi pada citra satelit Kota Langsa masing-masing tahun 2007 dan 2016 pada aplikasi Arc.Gis 10.3. Hasil penelitian didapatkan ada empat kelas lahan pertanian dan kehutanan yaitu persawahan, perkebunan, tambak, dan kehutanan yaitu hutan mangrove dengan total perubahan lahan keseluruhan di Kota Langsa yaitu 210,09 ha dengan rincian per kecamatan yakni Kecamatan Langsa Timur 47,19 Ha, Langsa Lama 35,68 ha, Langsa Barat 62,86 ha, Langsa Baro 48,87 ha, dan Langsa Kota 15,49 ha.
\end{abstract}

Kata Kunci : Penggunaan Lahan, Pertanian, Kehutanan, Alih Fungsi Lahan, Kota Langsa

\begin{abstract}
The research aim is to study the changes in agricultural and forest land use that occurred in each subdistrict of Langsa City within 10 years, started from 2007 to 2016. The change of land use detected by observing and digitizing the satellite images of Langsa City in 2007 and 2016 with the Arc.Gis 10.3 application. The results showed that there were four classes of agricultural dan forest land namely rice fields, plantations, ponds, and forestry, namely mangrove forest, with total of land use changes in Langsa city is 210.09 ha i.e. Langsa Timur 47.19 ha, Langsa Lama 35.68 ha, Langsa Barat 62.86 ha, Langsa Baro 48.87 ha, and Langsa Kota 15.49 ha.
\end{abstract}

Keywords: Land Use, Agriculture, Forest, Land Use Changes, Langsa City

\section{PENDAHULUAN}

Lahan adalah salah satu bagian alam yang memiliki lingkungan fisik diantaranya iklim, tanah, topografi, hidrologi, dan vegetasi yang sangat berpengaruh terhadap kondisi lahan. Lahan memiliki suatu komponen yang merupakan suatu sumberdaya yang mana berpengaruh dalam hubungan aktivitas manusia dalam kehidupannya (Worosuprojo, 2007).

Sejalan dengan bertambahnya penduduk, terjadi sebuah perebutan pemanfaatan lahan, yang menyebabkan terjadinya alih fungsi lahan. Misalnya konversi lahan sawah ke lahan pertanian kering ataupun ke penggunaan lahan urban seperti permukiman dan lain-lain. Lahan sawah yang dialih fungsikan biasanya terdapat di tempat strategis yang dapat dengan mudah dijangkau (Menaka, 2011).

Handoko (2016) mengartikan alih fungsi lahan dengan konversi lahan yaitu perubahan fungsi dari lahan tersebut menjadi fungsi lainnya yang dapat berdampak negatif bagi lingkungan dan lahan itu sendiri. Alih fungsi lahan tersebut disebabkan oleh faktor-faktor antara lain untuk memenuhi kebutuhan penduduk yang sejalan dengan bertumbuhnya penduduk setiap tahun guna untuk kehidupan yang lebih sejahtera.

Alih fungsi lahan umumnya sering terjadi untuk kegiatan pembangunan sarana-sarana kebutuhan publik. Winoto (2005) menyatakan bahwa sawah merupakan lahan yang paling rentan terjadinya alih fungsi. Hal ini dikarenakan (a) suatu wilayah yang memiliki kepadatan penduduk umumnya memiliki lahan dominan sawah dibanding lahan pertanian lainnya, (b) lahan sawah sering dijumpai di dekat perkotaan, (c) karena adanya pola pembangunan di masa lalu, infrastruktur di wilayah sawah lebih bagus ketimbang lahan pertanian kering, (d) 
pembangunan sarana dan prasarana lebih cepat di wilayah dataran datar yang mana sawah termasuk ke dalam kategori tersebut.

Berdasarkan uraian diatas, dapat diketahui bahwa alih fungsi lahan marak sekali terjadi akibat dari faktor-faktor pembangunan kebutuhan pemukiman sampai dengan pembangunan industri/pabrik. Oleh karena itu, penulis melakukan penelitian mengenai alih fungsi lahan atau perubahan penggunaan lahan pertanian dan kehutanan di Kota Langsa.

\section{METODE PENELITIAN}

Penelitian ini dilaksanakan di Kota Langsa (secara spasial dapat dilihat pada Lampiran 1) sedangkan analisis peta dilakukan di Laboratorium Penginderaan Jauh dan Kartografi Fakultas Pertanian Universitas Syiah Kuala. Penelitian ini dilaksanakan dari Desember 2017 sampai April 2018.

\section{Metode Penelitian}

\section{Analisis Kuantitatif}

Penelitian ini menggunakan metode analisis kuantitatif yang bertujuan untuk mempermudah dan memahami apa yang terdapat di balik semua data tersebut, mengelompokkannya, meringkasnya menjadi suatu yang kompak dan mudah dimengerti, serta menemukan pola umum yang timbul dari data tersebut, dalam hal ini dilakukan untuk mengetahui perubahan penggunaan lahan pertanian dan kehutanan di Kota Langsa.

\section{Pelaksanaan Penelitian}

\section{Pengumpulan Data}

Citra satelit Kota Langsa masing-masing tahun 2007 dan 2016 yang diunduh dari aplikasi Google Earth Pro, serta peta-peta dasar seperti peta batas administrasi, dan peta jenis tanah yang didapat dari instansi Badan Perencanaan Pembangunan Daerah (Bappeda).

\section{Pra pengolahan citra}

Pada tahap ini dilakukan koreksi geometrik. Koreksi geometrik ini memungkinkan pengguna untuk menyesuaikan sistem koordinat citra yang akan dianalisis. Dalam koreksi ini, biasanya sistem koordinat yang dipakai disesuaikan dengan sistem koordinat yang biasa dipakai di negara masing-masing. Kota Langsa memakai sistem koordinat UTM 47N. Citra satelit Kota Langsa masing-masing tahun 2007 dan 2016 dikoreksikan pada aplikasi ArcGIS 10.3.1.

\section{Analisa Data Spasial}

Pengolahan data spasial dilakukan dengan melakukan digitasi pada citra satelit Kota Langsa yang telah di unduh berupa gambar (JPEG) masing-masing tahun 2007 dan 2016. Pendigitasian citra Kota Langsa dilakukan berdasarkan ketentuan klasifikasi lahan menurut Badan Pertanahan Nasional (1977). Hasil dari digitasi ini adalah peta penggunaan lahan pertanian Kota Langsa tahun 2007 dan 2016. Lahan pertanian adalah lahan yang ditujukan atau cocok untuk dijadikan lahan usaha tani untuk memproduksi tanaman pertanian maupun hewan ternak. Lahan pertanian merupakan salah satu sumber daya utama pada usaha pertanian. Terdapat 2 jenis lahan pertanian, yaitu lahan basah dan kering. 
Setelah digitasi selesai, langkah selanjutnya yaitu memasukkan batas Kecamatan yang ada di Kota Langsa dengan menggunakan tool analisis clip. Clip adalah memotong suatu fitur atau shapefile dengan fitur lainnya. Fitur yang dimaksud yaitu peta penggunaan lahan Kota Langsa masing-masing tahun 2007 dan 2016 di potong dengan fitur batas Kecamatan Kota Langsa. Hasilnya adalah shapefile penggunaan lahan masing-masing Kecamatan yang ada di Kota Langsa, guna untuk mengkaji secara detail perubahan luas lahan per masing-masing Kecamatan.

Langkah berikutnya adalah menumpang tindihkan (union) peta penggunaan lahan tahun 2007 dengan tahun 2016 yang menghasilkan peta perubahan lahan pertanian di Kota Langsa dalam jangka waktu 10 tahun. Ini diperlukan untuk memperoleh informasi secara visual perubahan yang telah terjadi meliputi luas, bentuk, dan sebaran perubahan penggunaan lahan pertanian ke non pertanian maupun sebaliknya.

\section{HASIL DAN PEMBAHASAN}

\section{Penggunaan Lahan Pertanian dan Kehutanan Kota Langsa Tahun 2007}

Tahun 2007 merupakan enam tahun Kota Langsa sudah mekar dari Kabupaten Aceh Timur. Kondisi penggunaan lahan pertanian tahun 2007 pada kajian ini sebarannya terletak di semua Kecamatan di Kota Langsa. Secara detil dapat dilihat pada Tabel 1.

Tabel 1. Luas Lahan Pertanian dan Kehutanan Kota Langsa Tahun 2007

\begin{tabular}{lrrrrrr}
\hline Kecamatan & \multicolumn{1}{c}{$\begin{array}{c}\text { Sawah } \\
\text { (ha) }\end{array}$} & $\begin{array}{c}\text { Perkebunan } \\
\text { (ha) }\end{array}$ & Tambak (ha) & $\begin{array}{c}\text { Mangrove } \\
\text { (ha) }\end{array}$ & Jumlah (Ha) & $\begin{array}{c}\text { Persentase } \\
(\%)\end{array}$ \\
\hline Langsa Timur & $1.053,63$ & $1.208,07$ & $1.512,34$ & $2.788,61$ & $6.562,65$ & 38,9 \\
Langsa Lama & 180,87 & $2.197,89$ & 165,97 & 7,79 & $2.552,52$ & 15,13 \\
Langsa Barat & 222,62 & 9,23 & $2.375,26$ & $1.474,24$ & $4.081,35$ & 24,19 \\
Langsa Baro & 55,27 & $2.993,06$ & 319,67 & 162,34 & $3.530,34$ & 20,92 \\
Langsa Kota & 50,92 & 0,282 & 53,92 & 38,91 & 144,03 & 0,85 \\
\hline Jumlah (Ha) & $1.563,31$ & $6.408,53$ & $4.427,16$ & $4.471,89$ & $16.870,89$ & 100 \\
\hline
\end{tabular}

Luas lahan pertanian paling besar Kota Langsa tahun 2007 ada di Kecamatan Langsa Timur yaitu 6.562,65 ha dan yang paling kecil pada Kecamatan Langsa Kota yaitu 144,03 ha. Adapun penggunaan lahan pertanian paling besar yakni perkebunan dengan total luas $6.408,53$ ha, dan paling kecil yakni sawah yang mana memiliki luas 1.563,31 ha. Secara spasial dapat dilihat pada peta penggunaan lahan tahun 2007 pada Lampiran 2.

\section{Penggunaan Lahan Pertanian dan Kehutanan Kota Langsa Tahun 2016}

Seperti halnya tahun 2007, luas lahan pertanian di Kota Langsa tahun 2016 juga diperoleh dari hasil pendigitasian pada citra satelit Kota Langsa sebagaimana rincinya dapat dilihat pada Tabel 2.

Berdasarkan Tabel 2, luas lahan pertanian dan kehutanan yang paling besar masih ada di Kecamatan Langsa Timur yang mana hutan mangrove mengalami kenaikan dari tahun 2007 sebesar 4,3 ha, sedangkan yang lainnya mengalami penurunan jumlah luas. Hal ini disebabkan karena penanaman hutan mangrove guna untuk menciptakan tempat wisata di Kota Langsa. Secara spasial dapat dilihat melalui peta penggunaan lahan tahun 2016 pada Lampiran 3. 
Tabel 2. Luas Lahan Pertanian dan Kehutanan Kota Langsa Tahun 2016

\begin{tabular}{lcrrrrr}
\hline Kecamatan & $\begin{array}{c}\text { Sawah } \\
\text { (ha) }\end{array}$ & $\begin{array}{c}\text { Perkebunan } \\
\text { (ha) }\end{array}$ & Tambak (ha) & $\begin{array}{c}\text { Mangrove } \\
\text { (ha) }\end{array}$ & Jumlah (ha) & $\begin{array}{c}\text { Persentase } \\
\text { (\%) }\end{array}$ \\
\hline Langsa Timur & 975,40 & $1.235,79$ & $1.511,36$ & $2.792,91$ & $6.515,46$ & 39,11 \\
Langsa Lama & 137,71 & $2.199,62$ & 171,72 & 7,79 & $2.516,84$ & 15,11 \\
Langsa Barat & 162,44 & 9,23 & $2.215,87$ & $1.630,95$ & $4.018,49$ & 24,12 \\
Langsa Baro & 0 & $2.953,38$ & 346,96 & 181,13 & $3.481,47$ & 20,87 \\
Langsa Kota & 38,85 & 0,28 & 53,93 & 35,48 & 128,54 & 0,77 \\
\hline Jumlah (Ha) & $1.314,4$ & $6.398,3$ & $4.299,84$ & $4.648,26$ & $16.660,80$ & 100 \\
\hline
\end{tabular}

\section{Perubahan Penggunaan Lahan Pertanian dan Kehutanan Kota Langsa Tahun 2007 - 2016}

Perubahan penggunaan lahan merupakan fenomena global yang menjadi perhatian peneliti di berbagai negara di dunia. Kajian perubahan penggunaan lahan berkembang sangat cepat dan menghasilkan banyak pendekatan. Kondisi demikian berlaku juga untuk Kota Langsa, yang mana dalam kurun waktu 10 tahun (2007-2016), terjadi perubahan penggunaan lahan. Perubahan terjadi sebanyak 210,09 ha. Secara rinci dapat dilihat pada Tabel 3.

Tabel 3. Luas Perubahan Lahan Pertanian dan Kehutanan di Kota Langsa

\begin{tabular}{|c|c|c|c|c|c|}
\hline \multirow{2}{*}{ Kecamatan } & \multirow{2}{*}{ Penggunaan Lahan } & \multicolumn{2}{|c|}{ Luas (ha) } & \multirow{2}{*}{ Perubahan (ha) } & \multirow{2}{*}{$\begin{array}{c}\text { Jumlah } \\
\text { Perubahan (ha) }\end{array}$} \\
\hline & & 2007 & 2016 & & \\
\hline \multirow{4}{*}{ Langsa Timur } & Sawah & $1.053,63$ & 975,4 & 78,23 & \multirow{4}{*}{47,19} \\
\hline & Perkebunan & $1.208,07$ & $1.235,79$ & $-27,72$ & \\
\hline & Tambak & $1.512,34$ & $1.511,36$ & 0,98 & \\
\hline & Mangrove & $2.788,61$ & $2.792,91$ & $-4,30$ & \\
\hline \multirow{4}{*}{ Langsa Lama } & Sawah & 180,87 & 137,71 & 43,16 & \multirow{4}{*}{35,68} \\
\hline & Perkebunan & $2.197,89$ & $2.199,62$ & $-1,73$ & \\
\hline & Tambak & 165,97 & 171,72 & $-5,75$ & \\
\hline & Mangrove & 7,79 & 7,79 & 0,00 & \\
\hline \multirow{4}{*}{ Langsa Barat } & Sawah & 222,62 & 162,44 & 60,18 & \multirow{4}{*}{62,86} \\
\hline & Perkebunan & 9,23 & 9,23 & 0,00 & \\
\hline & Tambak & $2.375,26$ & $2.215,87$ & 159,39 & \\
\hline & Mangrove & $1.474,24$ & $1.630,95$ & $-156,71$ & \\
\hline \multirow{4}{*}{ Langsa Baro } & Sawah & 55,27 & 0 & 55,27 & \multirow{4}{*}{48,87} \\
\hline & Perkebunan & $2.993,06$ & $2.953,38$ & 39,68 & \\
\hline & Tambak & 319,67 & 346,96 & $-27,29$ & \\
\hline & Mangrove & 162,34 & 181,13 & $-18,79$ & \\
\hline \multirow{4}{*}{ Langsa Kota } & Sawah & 50,92 & 38,85 & 12,07 & \multirow{4}{*}{15,49} \\
\hline & Perkebunan & 0,282 & 0,28 & 0,00 & \\
\hline & Tambak & 53,92 & 53,93 & $-0,01$ & \\
\hline & Mangrove & 38,91 & 35,48 & 3,43 & \\
\hline \multicolumn{2}{|c|}{ Jumlah (ha) } & $16.870,89$ & $16.660,8$ & 210,09 & \\
\hline
\end{tabular}

Tabel 3 memperlihatkan bahwa perubahan penggunaan lahan paling besar ada pada Kecamatan Langsa Barat dengan nilai perubahan sebanyak 62,86 ha dan perubahan paling sedikit ada pada Kecamatan Langsa Kota yakni senilai 15,49 ha. Hal ini karena sedikitnya lahan pertanian yang ada di Kecamatan Langsa Kota. Langsa Barat banyak mengalami perubahan karna terjadi alih fungsi lahan sawah menjadi pemukiman. Lebih lanjut kajian Josan (2016) menyatakan bahwasanya lahan-lahan di Kota yang baru berkembang, dapat terjadi alih fungsi yang diduga menjadi penyebab semakin berkurangnya jumlah lahan sawah. 
Langsa Kota lebih sedikit berubah karna memang diperuntukkan untuk daerah perkotaan sehingga bangunan lebih dominan daripada lahan pertanian.

Berdasarkan Tabel 3, penggunaan lahan pertanian dan kehutanan tidak seluruhnya mengalami penurunan luas. Kebanyakan terjadi pada penggunaan lahan hutan mangrove. Hal ini karena seperti yang sudah dijelaskan sebelumnya bahwa dikarenakan penanaman hutan mangrove dengan tujuan untuk objek wisata Kota Langsa.

Proses perubahan penggunaan lahan merupakan suatu fenomena yang dinamis dan hubungannya dengan pertumbuhan penduduk, perubahan orientasi ekonomi dan kebijakan pemerintah. Hal ini sesuai dengan yang dikemukakan oleh Santun (2012), bahwa segala aspek kelembagaan yang menyangkut dengan kebijakan pemerintah menjadi pendorong dalam perubahan penggunaan lahan.

Hal tersebut juga berlaku untuk Kota Langsa, yang mana alih fungsi lahan berdasarkan hasil union peta penggunaan lahan Kota Langsa tahun 2007 dan 2016 secara detil dapat dilihat pada Tabel 4, dan secara spasial dapat dilihat pada Lampiran 4.

Tabel 4. Perubahan Penggunaan Lahan Kota Langsa Tahun 2007 dan 2016

\begin{tabular}{|c|c|c|c|}
\hline Penggunaan Lahan 2007 & Persentase (\%) & Penggunaan Lahan 2016 & Persentase (\%) \\
\hline 1 & 2 & 3 & 4 \\
\hline \multirow{3}{*}{ Hutan } & 12,87 & Hutan & 12,79 \\
\hline & & Perkebunan & 0,030 \\
\hline & & Permukiman & 0,049 \\
\hline Fasilitas Umum & 0,96 & Fasilitas umum & 0,96 \\
\hline \multirow[t]{3}{*}{ Hutan mangrove } & 18,64 & Fasilitas umum & 0,015 \\
\hline & & Hutan mangrove & 18,62 \\
\hline & & Permukiman & 0,010 \\
\hline \multirow[t]{5}{*}{ Perkebunan } & 26,73 & Fasilitas umum & 0,083 \\
\hline & & Hutan & 0,060 \\
\hline & & Perkebunan & 26,40 \\
\hline & & Permukiman & 0,099 \\
\hline & & Tanah terbuka & 0,077 \\
\hline \multirow[t]{6}{*}{ Permukiman } & 8,09 & Fasilitas umum & 0,040 \\
\hline & & Hutan & 0,0018 \\
\hline & & Pemukiman & 0,006 \\
\hline & & Perkebunan & 0,010 \\
\hline & & Permukiman & 8,033 \\
\hline & & Tanah terbuka & 0,00016 \\
\hline \multirow[t]{6}{*}{ Persawahan } & 6,50 & Fasilitas umum & 0,0580 \\
\hline & & Hutan & 0,00343 \\
\hline & & Perkebunan & 0,212 \\
\hline & & Permukiman & 0,324 \\
\hline & & Persawahan & 5,54 \\
\hline & & Tanah terbuka & 0,360 \\
\hline \multirow[t]{5}{*}{ Tambak } & 18,59 & Fasilitas umum & 0,006 \\
\hline & & Hutan mangrove & 0,754 \\
\hline & & Permukiman & 0,058 \\
\hline & & Tambak & 17,72 \\
\hline & & Tanah terbuka & 0,054 \\
\hline \multirow[t]{5}{*}{ Tanah terbuka } & 2,57 & Fasilitas umum & 0,078 \\
\hline & & Perkebunan & 0,015 \\
\hline & & Permukiman & 0,251 \\
\hline & & Tambak & 0,110 \\
\hline & & Tanah terbuka & 2,11 \\
\hline Total & 100 & & 100 \\
\hline
\end{tabular}


Tabel 4 menunjukkan bahwa banyak lahan pertanian yang sudah beralih fungsi. Salah satu contoh yaitu penggunaan lahan yang awalnya adalah tambak $(18,59 \%)$ pada tahun 2007 , pada tahun 2016 sudah mengalami perubahan luas yakni menjadi $17,72 \%$ yang mana $0,87 \%$ sudah beralih fungsi lahan menjadi fasilitas umum $(0,006 \%)$, hutan mangrove $(0,754 \%)$, permukiman $(0,058 \%)$, dan tanah terbuka $(0,054 \%)$. Begitu juga dengan alih fungsi lahan lainnya seperti sawah, hutan mangrove, dan perkebunan.

\section{KESIMPULAN DAN SARAN}

Terjadi perubahan penggunaan lahan pertanian sebesar 210,09 hektar. Perubahan paling banyak terdapat pada Kecamatan Langsa Barat dan yang paling sedikit terdapat pada Kecamatan Langsa Kota. Jenis penggunaan lahan pertanian dan kehutanan yang ada antara lain sawah, perkebunan, tambak, dan mangrove.

\section{DAFTAR PUSTAKA}

BPN. 1977. Penggunaan Tanah (Land Use) di Indonesia Publikasi No 75. Jakarta : Direktorat tata Guna Tanah Dirjen Agraria Departemen dalam Negeri.

Handoko. 2016. Alih fungsi (konversi) lahan pertanian ke non pertanian kasus di Kelurahan Simpang Pasir Kecamatan Palaran. Samarinda, 2016.

Josan. 2016. Analisis perubahan penggunaan lahan sawah menjadi permukiman di Kabupaten Pringsewu Tahun 2012-2014. Skripsi. Universitas Lampung, Lampung.

Menaka, N. R. d. G. 2011. Persaingan pemanfaatan lahan dan air. Udayana University Press, Denpasar-Bali.

Santun. 2012. Analisis pola perubahan penggunaan lahan dan perkembangan wilayah di Kota Bekasi Provinsi Jawa Barat. Jurnal Tanah Lingkungan, 14: 21.

Winoto, J. 2005. Kebijakan pengendalian alih fungsi tanah pertanian dan implementasinya. kerjasama kantor kementerian koordinator bidang perekonomian dengan pusat studi pembangunan pertanian dan pedesaan. Institut Pertanian Bogor, Jakarta.

Worosuprojo. 2007. Pengelolaan sumberdaya lahan berbasis spasial dalam pembangunan berkelanjutan di Indonesia. Makalah Pidato Pengukuhan Guru Besar UGM, Yogyakarta. 
Lampiran 1. Peta Kawasan Kajian Penelitian

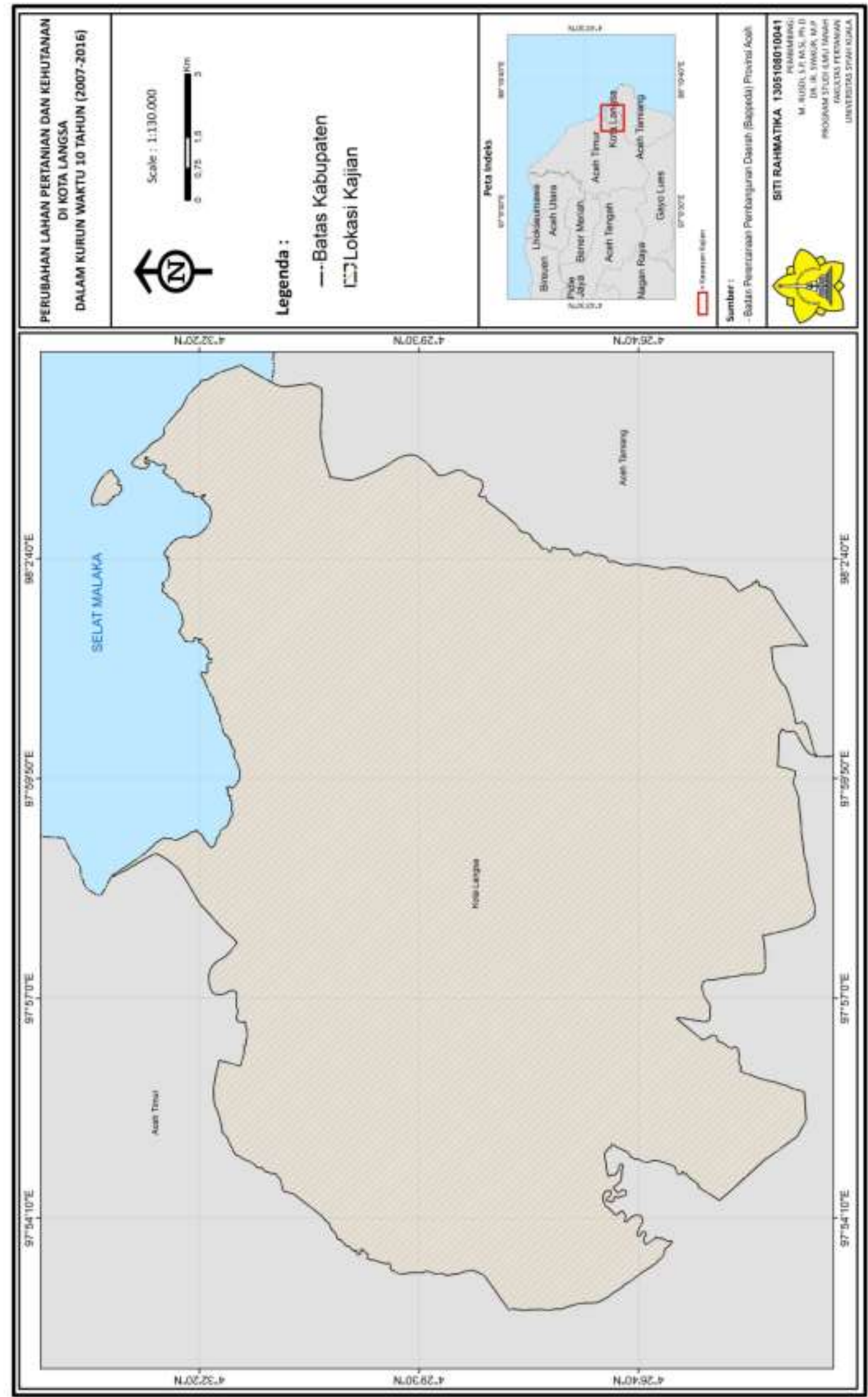

Perubahan Lahan Pertanian dan Kehutanan di Kota Langsa dalam Kurun Waktu 10 Tahun (2007 - 2016) 
Lampiran 2. Peta Penggunaan Kota Langsa Tahun 2007

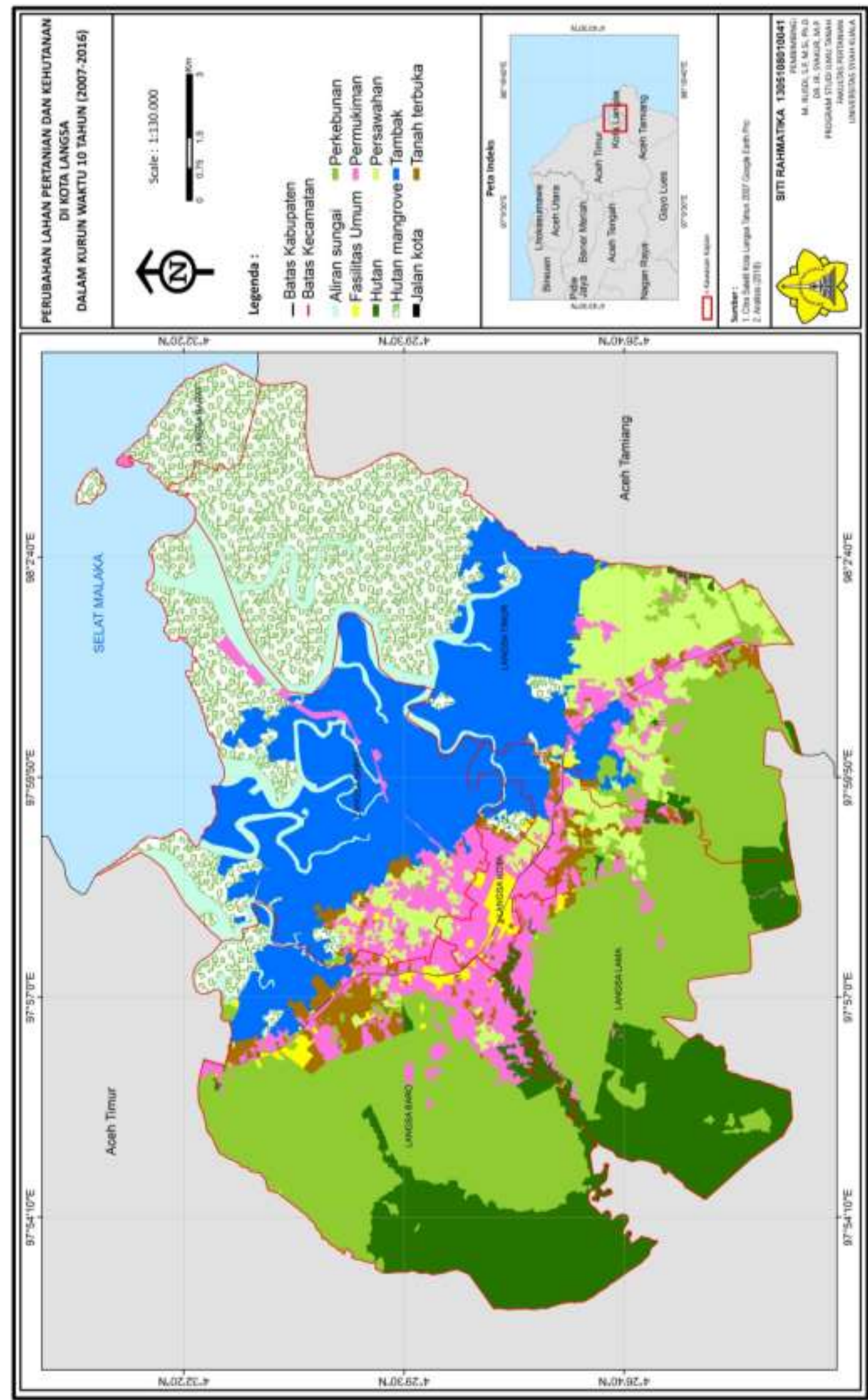

Perubahan Lahan Pertanian dan Kehutanan di Kota Langsa dalam Kurun Waktu 10 Tahun (2007 - 2016) 
Lampiran 3. Peta Penggunaan Kota Langsa Tahun 2016

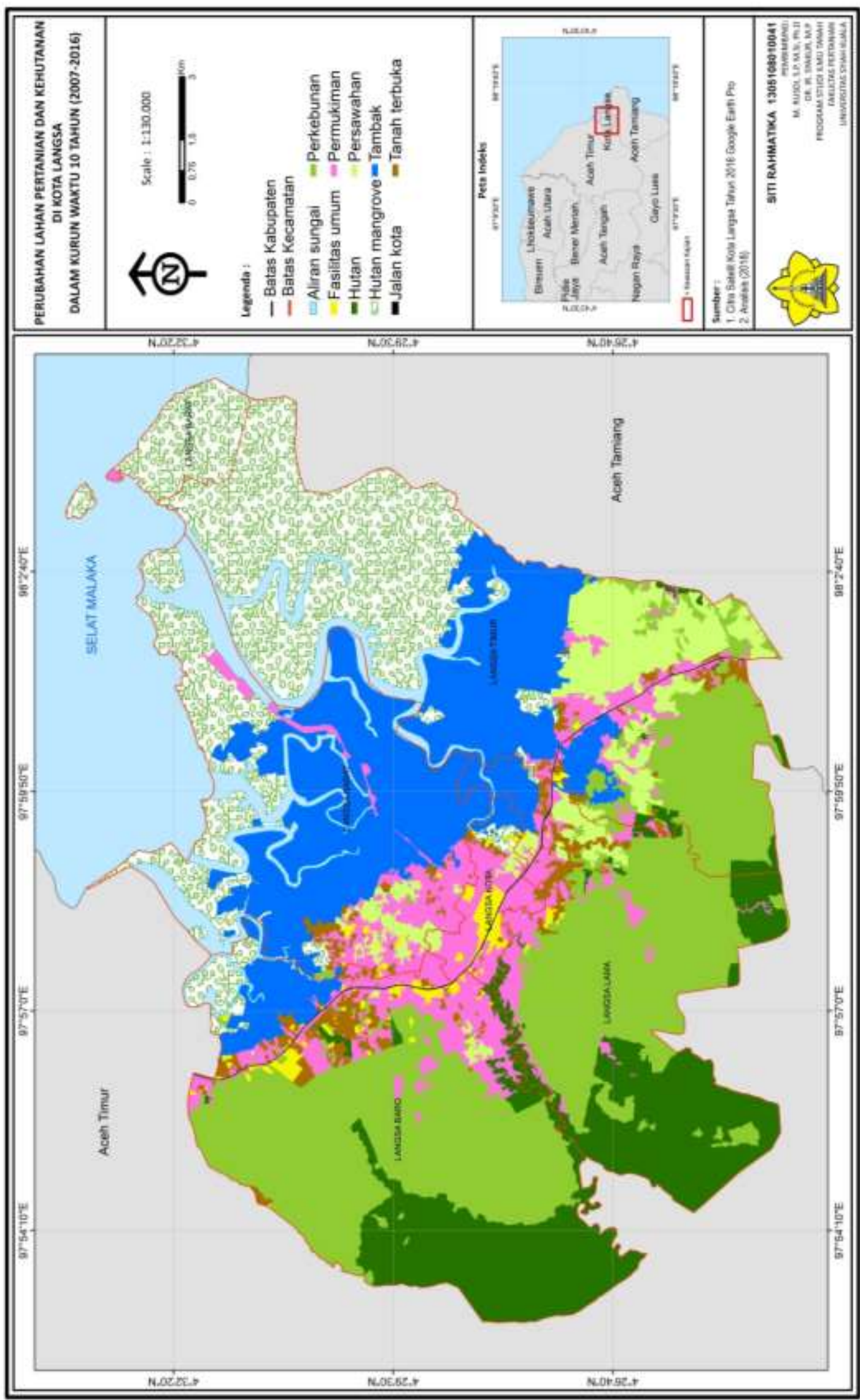

Perubahan Lahan Pertanian dan Kehutanan di Kota Langsa dalam Kurun Waktu 10 Tahun (2007 - 2016) 
Lampiran 4. Peta Perubahan Penggunaan Kota Langsa Tahun 2007- 2016

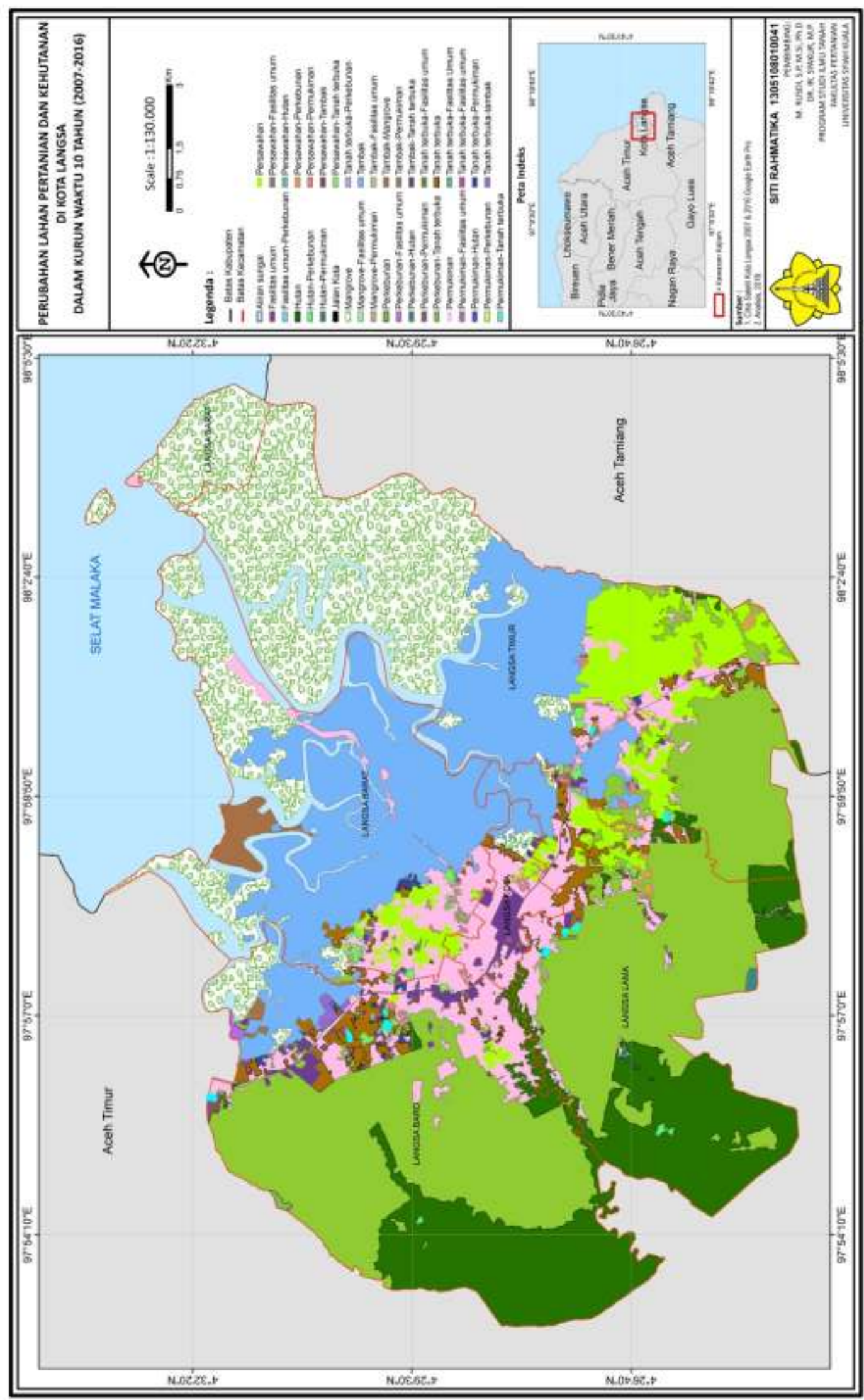

Perubahan Lahan Pertanian dan Kehutanan di Kota Langsa dalam Kurun Waktu 10 Tahun (2007 - 2016) 